\title{
Biowastes of slaughterhouses and wet markets: an overview of waste management for disease prevention
}

\author{
Adel Al-Gheethi ${ }^{1}$ - Nyuk Ling Ma ${ }^{2}$ Parveen Fatemeh Rupani ${ }^{3}$ (D) Naznin Sultana ${ }^{4}$ - Maizatul Azrina Yaakob ${ }^{5}$ \\ Radin Maya Saphira Radin Mohamed ${ }^{1}$. Chin Fhong Soon ${ }^{6}$
}

Received: 16 December 2020 / Accepted: 16 September 2021

(C) The Author(s), under exclusive licence to Springer-Verlag GmbH Germany, part of Springer Nature 2021

\begin{abstract}
Slaughterhouse and wet market wastes are pollutants that have been always neglected by society. According to the Food and Agriculture Organization of the United Nations, more than three billion and nineteen million livestock were consumed worldwide in 2018, which reflects the vast amount and the broad spectrum of the biowastes generated. Slaughterhouse biowastes are a significant volume of biohazards that poses a high risk of contamination to the environment, an outbreak of diseases, and insecure food safety. This work comprehensively reviewed existing biowaste disposal practices and revealed the limitations of technological advancements to eradicate the threat of possible harmful infectious agents from these wastes. Policies, including strict supervision and uniform minimum hygienic regulations at all raw food processing factories, should therefore be tightened to ensure the protection of the food supply. The vast quantity of biowastes also offers a zero-waste potential for a circular economy, but the incorporation of biowaste recycling, including composting, anaerobic digestion, and thermal treatment, nevertheless remains challenging.
\end{abstract}

Keywords Bacteria $\cdot$ Disease transmission $\cdot$ Sustainable management $\cdot$ Biological treatment $\cdot$ Hazards' risk $\cdot$ Recycle

\section{Introduction}

Inedible animal body parts that represent $45 \%$ of slaughtered animals, which include the tissues, blood, blood vessels, feathers, and bones, are major constituents of slaughterhouse and wet market wastes that are ultimately sent for disposal or recycling (Franke-Whittle and Insam 2013). The disposal of these substantial amounts of wastes is challenging for the meat, aquatic, and poultry industries due to several legal

Adel Al-Gheethi and Nyuk Ling Ma are both first authors and contribute the same in the manuscript.

Responsible Editor: Ta Yeong Wu

Parveen Fatemeh Rupani

parveen@ujs.edu.cn

Chin Fhong Soon

soon@uthm.edu.my

1 Micropollutant Research Centre (MPRC), Faculty of Civil Engineering \& Built Environment, Universiti Tun Hussein Onn Malaysia, 86400 Parit Raja, Batu Pahat, Johor, Malaysia

2 Faculty of Science and Marine Environment, University Malaysia Terengganu, 21030 Kuala Terengganu, Terengganu, Malaysia restraints and ever-rising processing costs associated with disposal. Unsafe and improper disposal of such wastes can lead to tremendous ecological troubles. Table 1 shows the physicochemical properties of biowastes generated in slaughterhouses and wet markets globally. The contents of slaughterhouse and wet market biowastes, such as moisture, organic carbon solids, and elements such as potassium, are potentially reservoirs for microbial diseases (Mensah-Attipoe and Toyinbo 2019).
School of Energy and Power Engineering, Jiangsu University, Zhenjiang 212013, Jiangsu, China

4 Medical Academy, Prairie View A\&M University, Prairie View, TX 77446, USA

5 Institute for Integrated Engineering, Universiti Tun Hussein Onn Malaysia, 86400 Parit Raja, Batu Pahat, Johor, Malaysia

6 Microelectronics and Nanotechnology-Shamsuddin Research Centre, Institute for Integrated Engineering, Universiti Tun Hussein Onn Malaysia, 86400 Parit Raja, Batu Pahat, Johor, Malaysia 
Table 1 Physicochemical properties of slaughterhouse and wet market biowastes (NR indicates non-reported)

\begin{tabular}{|c|c|c|c|c|c|}
\hline \multirow{2}{*}{$\begin{array}{l}\text { Physicochemical } \\
\text { properties }\end{array}$} & \multicolumn{2}{|c|}{ Slaughterhouse } & \multicolumn{3}{|l|}{ Wet market } \\
\hline & $\begin{array}{l}\text { Sengupta } \\
\text { (2004) }\end{array}$ & $\begin{array}{l}\text { Gendebien et al. } \\
\text { (2001) }\end{array}$ & $\begin{array}{l}\text { Tweib et al. } \\
\text { (2011) }\end{array}$ & $\begin{array}{l}\text { Lohri et al. } \\
\text { (2016) }\end{array}$ & $\begin{array}{l}\text { Lou et al. } \\
\text { (2015) }\end{array}$ \\
\hline Moisture & $69.45 \%$ & NR & $60 \%$ & $22.3 \%$ & $75.5 \pm 6.4 \%$ \\
\hline Total solids & $30.55 \%$ & $10-180 \mathrm{~g} / \mathrm{m}^{3}$ & $510.48 \mathrm{~kg} / \mathrm{m}^{3}$ & $25.9 \%$ & $\begin{array}{c}34.7 \pm 2.3 \\
\mathrm{~kg} / \mathrm{m}^{3}\end{array}$ \\
\hline Volatile solids & $87.95 \%$ & $10-107 \mathrm{~g} / \mathrm{m}^{3}$ & NR & $87.2 \%$ & NR \\
\hline Fixed solids & $12.05 \%$ & NR & NR & NR & NR \\
\hline Organic carbon & $23.32 \%$ & NR & $45.16 \%$ & $12.8 \%$ & $35.2 \pm 0.7 \%$ \\
\hline Total nitrogen & $2.71 \%$ & NR & $1.4 \%$ & $1.5 \%$ & $2.0 \pm 0.1 \%$ \\
\hline Phosphorus & $4.19 \mathrm{mg} / \mathrm{g}$ & NR & $\begin{array}{l}110970.826 \\
\mathrm{ppb}\end{array}$ & NR & NR \\
\hline Potassium & $6.9 \mathrm{mg} / \mathrm{g}$ & NR & NR & NR & NR \\
\hline Organic nitrogen & NR & $2-18 \mathrm{~g} / \mathrm{m}^{3}$ & NR & NR & NR \\
\hline Ammonia nitrogen & NR & $0.6-2.2 \mathrm{~g} / \mathrm{m}^{3}$ & NR & NR & NR \\
\hline $\mathrm{pH}$ & NR & NR & 6.2 & NR & $5.69 \pm 0.01$ \\
\hline
\end{tabular}

In addition, the improper disposal of slaughterhouse biowastes (SH-biowastes) has caused harmful algal blooms in surface water (Arvanitoyannis and Kassaveti 2008) and the contamination of groundwater from antibiotics from the poultry production (Alam et al. 2019), therefore raising safety concerns. However, the implementation of proper waste management has been limited by legal restraints, cost affordability, and available technologies. To date, several regulations for SH-biowaste treatment in minimizing pathogen transmission have been enforced, such as manure composting regulations by the Environmental Protection Agency (EPA)(Erickson et al. 2014), SH-biowaste thermal treatment regulations by the Canadian Food Inspection Agency (CFIA)(Adhikari et al. 2018), and pathogen disease transmission and ethical regulation (Regulation (EC) No 1774/2002) by the European Union (Russ and Meyer-Pittroff2004). With the recent SARSassociated coronavirus (SARS-CoV) outbreak from a wet market, the proper management of wet markets, including most slaughterhouses, is being put under the spotlight. Hence, more transparent management is demanded. Although burial and burning are the most common disposal methods of animal wastes in underdeveloped countries (Anon 2002), the developed countries do not allow similar approaches. For example, the European Union controls the dumping by incineration through licensed waste collectors (NABC 2004). The use of modern incineration plants as the standard practice to manage $\mathrm{SH}$-biowastes in most developed countries is favorable, as this method effectively kills all microbes (Alnahas et al. 2020). The biowaste composition from slaughterhouses and wet markets might be different from one region to another due to the population's location, lifestyle, and food consumption (Lohri et al. 2016). Differences in biowaste composition should be considered when implementing efficient treatment techniques. Hence, integrated recycling technologies for slaughterhouse and wet market waste management are essential for the safe disposal of wastes and the removal of various infectious agents.

This review therefore highlights the current technology gaps in waste management practices based on the sources of SH-biowaste components and the implications on the ecosystem and human health. Proper implementation of waste management can reduce environmental and health issues, while introducing new business opportunities that will ultimately benefit economic growth.

\section{Slaughterhouse and wet market wastes}

Biowastes generated from the food industry (slaughterhouses and wet markets) are from a broad spectrum and are derived from different stages of food processing, and the wastes are classified into solid wastes and wastewater (Ho and Chu 2019; Ratnawati and Trihadiningrum 2014). SH-biowastes contain a high proportion of organic materials, but these are not suitable for human consumption. The typical body composition of different edible animals is presented in Table 2. Hot carcass is the body of an animal after the removal of internal organs. Generally, 49-76\% of hot carcass is generated from cattle, $38-47 \%$ from sheep and goats, $44-48 \%$ from pigs, and $37-$ $40 \%$ from broilers (Shija et al. 2013).

In small slaughterhouses in developing countries, the dressing of carcasses, the removal of hides, and evisceration are performed on the floor, which is also the location for cutting the edible portion of the slaughtered animals (Fearon et al. 2014). Slaughter and evisceration are performed in a simple process. The abattoirs' wastewater and solid wastes are 
Table 2 Typical body compositions of calf, sheep, goat, pig, broiler chicken and duck (NR indicates non-reported)

\begin{tabular}{|c|c|c|c|c|}
\hline Animal & Component & $\begin{array}{l}\text { Weight (kg) } \\
\text { Mean } \pm \text { SE }\end{array}$ & Percentage $(\%)$ & Reference \\
\hline \multirow[t]{4}{*}{ Calf } & Body (18 months) & $414.50 \pm 20.5$ & 100 & \multirow[t]{4}{*}{ Oh et al. (2008) } \\
\hline & Hot carcass & $250.70 \pm 8.62$ & 60.38 & \\
\hline & Boneless meat & $173.74 \pm 3.53$ & 41.90 & \\
\hline & Trimmed carcass fat & $24.76 \pm 4.67$ & 5.98 & \\
\hline \multirow[t]{12}{*}{ Sheep } & Body (14 to 24 months) & $22.29 \pm 0.55$ & 100 & \multirow[t]{12}{*}{ Shija et al. (2013) } \\
\hline & Hot carcass & $9.43 \pm 0.03$ & 42.30 & \\
\hline & Gastrointestinal tract & $3.53 \pm 0.10$ & 15.84 & \\
\hline & Head & $1.59 \pm 0.04$ & 7.90 & \\
\hline & Skin & $1.66 \pm 0.05$ & 8.23 & \\
\hline & Feet & $0.52 \pm 0.02$ & 2.61 & \\
\hline & Internal organs & $0.94 \pm 0.03$ & 4.70 & \\
\hline & Kidneys & $0.07 \pm 0.01$ & 0.35 & \\
\hline & Internal fats & $0.07 \pm 0.03$ & 0.36 & \\
\hline & Testicles & $0.23 \pm 0.02$ & 1.16 & \\
\hline & Tail & $0.59 \pm 0.04$ & 2.91 & \\
\hline & Total non-carcass & $7.76 \pm 0.17$ & 38.58 & \\
\hline \multirow[t]{12}{*}{ Goat } & Body (14 to 24 months) & $20.50 \pm 0.55$ & 100 & \multirow[t]{12}{*}{ Diarra et al. (2015) } \\
\hline & Hot carcass & $9.68 \pm 0.03$ & 47.20 & \\
\hline & Gastrointestinal tract & $3.09 \pm 0.10$ & 15.10 & \\
\hline & Head & $1.27 \pm 0.04$ & 6.83 & \\
\hline & Skin & $1.39 \pm 0.05$ & 7.44 & \\
\hline & Feet & $0.56 \pm 0.02$ & 3.02 & \\
\hline & Internal organs & $0.97 \pm 0.03$ & 5.24 & \\
\hline & Kidneys & $0.08 \pm 0.01$ & 0.44 & \\
\hline & Internal fats & $0.11 \pm 0.03$ & 0.59 & \\
\hline & Testicles & $0.09 \pm 0.02$ & 1.02 & \\
\hline & Tail & $0.02 \pm 0.04$ & 0.10 & \\
\hline & Total non-carcass & $6.68 \pm 0.17$ & 35.84 & \\
\hline \multirow[t]{9}{*}{ Pig } & Body & NR & 100 & \multirow[t]{9}{*}{ Goldstrand (1992) } \\
\hline & Carcass meat & NR & 52 & \\
\hline & Bones & NR & 17 & \\
\hline & Organ & NR & 7 & \\
\hline & Skin and attached fats & NR & 6 & \\
\hline & Blood & NR & 3 & \\
\hline & Fatty tissues & NR & 3 & \\
\hline & Horns, huff, feet, and skull & NR & 6 & \\
\hline & Abdominal and intestinal contents & NR & 6 & \\
\hline \multirow[t]{9}{*}{ Broiler chicken } & Body (42 days) & 2.19 & 100 & \multirow[t]{9}{*}{ Diarra et al. (2015) } \\
\hline & Dressing & 1.79 & 81.52 & \\
\hline & Carcass cut-up parts & 0.894 & 40.83 & \\
\hline & Liver weight & 0.046 & 2.12 & \\
\hline & Pancreas & 0.004 & 0.18 & \\
\hline & Gizzard weight & 0.027 & 1.25 & \\
\hline & Heart & 0.011 & 0.52 & \\
\hline & Small intestine & 0.012 & 0.55 & \\
\hline & Abdominal fat pad & 0.0007 & 0.30 & \\
\hline \multirow[t]{3}{*}{ Duck } & Body (7 weeks) & $3.42 \pm 1.02$ & 100 & \multirow[t]{3}{*}{ Wawro et al. (2004) } \\
\hline & Carcass & $2.43 \pm 0.76$ & 71 & \\
\hline & Giblets & $0.16 \pm 0.05$ & 4.6 & \\
\hline
\end{tabular}


Table 2 (continued)

\begin{tabular}{|c|c|c|c|c|}
\hline Animal & Component & $\begin{array}{l}\text { Weight (kg) } \\
\text { Mean } \pm \text { SE }\end{array}$ & Percentage (\%) & Reference \\
\hline & Abdominal fat & $0.07 \pm 0.03$ & 2 & \\
\hline & Total meat & $1.189 \pm 0.382$ & 35 & \\
\hline
\end{tabular}

directly disposed into water bodies and lands adjacent to the abattoirs, creating pollution problems (Fearon et al. 2014). This is due to inadequate waste management and treatment facilities.

In contrast, modern abattoirs in developed countries are found in enclosed buildings with specific process lines for different types of slaughtered animals. The abattoirs are well-established with waste management processes for separating blood, screening of solids, and trapping of grease, which are aided with a conveyor line system (Woodard, Curran, Inc 2006). Blood is collected for stockfeed or fertilizer production. In waste treatment plants, bulk animal carcass incinerators are used to render animal wastes into ashes that can be used as fertilizers. Solid wastes, such as hides, hairs, intestines, and hooves, are screened and sorted for animal feed or disposal. Large amounts of water are used for the cleaning process, which results in effluents that contain solidified lipids. In advanced wastewater processing plants, grease, oil, fat, floating and suspended solids, and settling materials that rise to the surface of the water are removed regularly using mechanical pre-treatment systems, such as the micro strainer, rotary drum fine screener, and screw conveyor (for example, the Huber technology from Germany). Wastewater from the abattoirs is processed using a full automation system and further treated before being discharged into municipal sewers. In modern abattoirs, all animal wastes are recycled, while ensuring minimum effects to the environment.

The wastewater produced by the meat processing industry has increased tremendously in recent years (Aleksic et al. 2020). According to the Food and Agriculture Organization (FAO) of the United Nations (FAO 2021), the demand for broiler chicken and meat is growing faster than any other meat type. Other types of poultry, such as duck, turkey, guinea fowl, pigeon, and geese, are far less consumed, which is 1.2 billion per year (FAO 2021). The number of chickens slaughtered, at approximately 24.5 billion per year, surpasses those of pigs and cattle (Fig. 1). Moreover, the amount of water required by processing poultry is an average of $15 \mathrm{~L}$ per bird, which could add up to a few hundred billion liters of wastewater each year (Matsumura and Mierzwa 2008). Effluents from meat processing are recognized as harmful and threatening due to the complex composition of fibers, proteins, fats, high organic contents, pathogens, and veterinary pharmaceuticals (Bustillo-Lecompte and Mehrvar
2017; Chang et al. 2010). The chemical contents of wastewater from slaughterhouses are almost similar to municipal sewage (Damaceno et al. 2019). These induce algal blooms that limit oxygen supply for the aquatic life and cause microbiological contaminations of water bodies. Hence, the implications of the astonishing volume and wide range of $\mathrm{SH}$ biowastes disposed into the ecological system from slaughterhouses and wet markets should not be disregarded (Fig. 2).

The major biowastes from marine products are from fish, representing 76 million tons, mostly from wholesalers and the seafood processing industry that processed canned and frozen fish (Ching-Velasquez et al. 2020). Majority of seafood are processed in shore-based processing facilities near the ports. During the processing of demersal fish, for instance, the viscera, frame, skin, fin, and head are usually discarded as waste (Ravanipour et al. 2021). The waste products of shellfish are shells and viscera. The inedible portions of some demersal species and shellfish, as outlined in Table 3, are usually discarded. However, aquatic wastes are considered valuable by-products that are recyclable as fertilizers, animal feed, dietetic products, natural colorings, biodiesel, and enzymes (Arvanitoyannis and Kassaveti 2008). In addition, every thousand $\mathrm{kg}$ of fish production during skinning and canning generated 15 to 17 liters of wastewater (Arvanitoyannis and Kassaveti 2008), and these effluents consist of feces, antibiotics, fish feed, and components that are rich in protein and can be post-processed to be used as animal feed or manure. However, effluents from the fish processing industry are often released directly into the shallow coastal water, leaving impacts on the aquatic environment (Arvanitoyannis and Ladas 2008).

\section{Ecological and health implications}

Wet market and slaughterhouse facilities are usually located near water bodies, and therefore, untreated or partially treated effluents of these facilities commonly ended up in the water bodies (Fig. 2). SH-biowastes generated from slaughterhouses contain a high level of organic compounds, which could lead to rapid oxygen consumption by microorganisms, resulting in an anoxia condition in water bodies (Adeyemo 2002). Hence, the anaerobic stage causes an insufficient amount of dissolved oxygen for aquatic life and plants. Consequently, the high 
Fig. 1 Animal production by country, 2018 (Food and

Agriculture Organization United

Nation, http://www.fao.org/

faostat/en/, 2018) (a)

Cattle

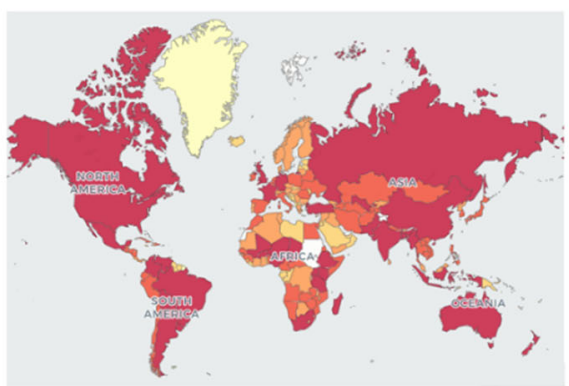

Head

$<=29558$

는 $<=467318$

1] $<=1996358$

- $>7520274$

(b)

Sheep

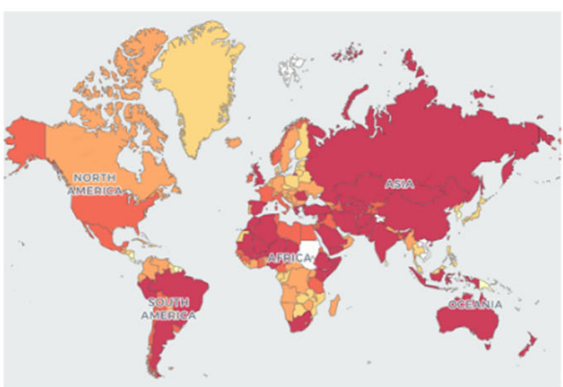

Head

$<=13861$

$<=13861$
$<=309992$

$<=2208000$

$<=8683835$

口 $>8683835$

(c)

Goat

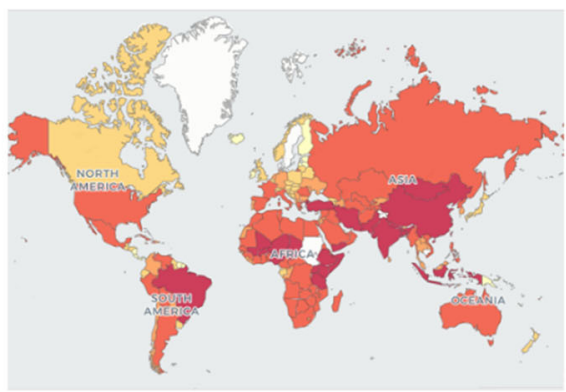

Head

$<=13262$

$<=114131$

$<=970668$

$<=8749589$

$>8749589$

(d)

Pig

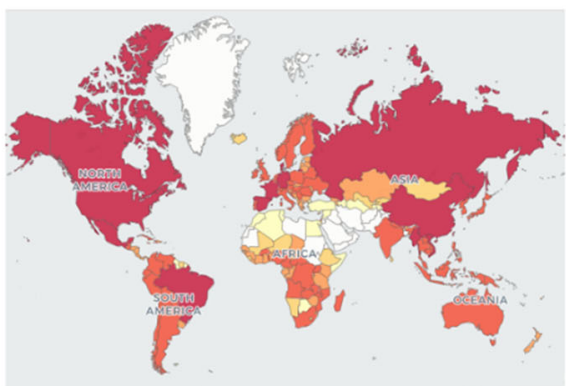

Head

$<=10500$

$<=100581$

11 $<=798732$

$<=12604441$

- 12604441

(e)

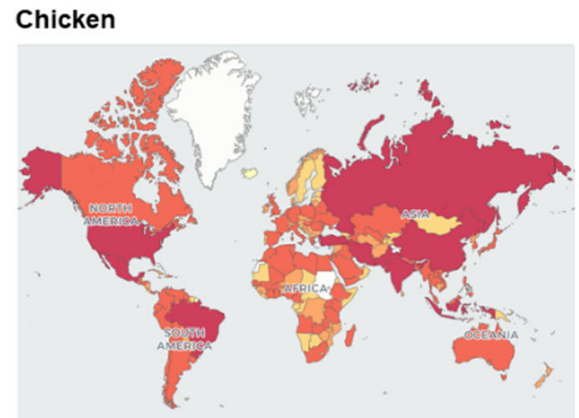

1000 heac

$<=800$
$<=9196$

$-<=25829$

$<=323125$

- 323125 


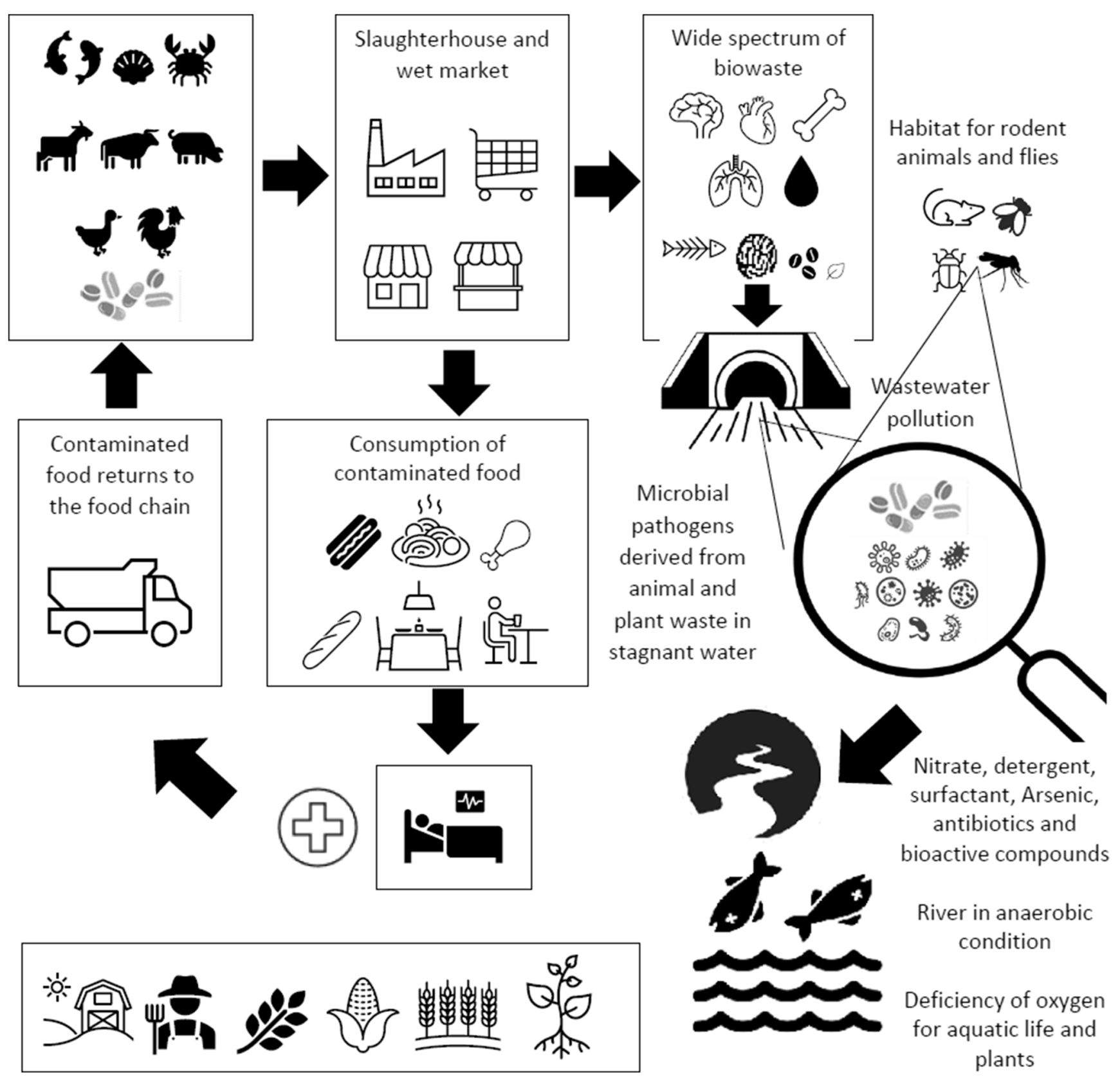

Fig. 2 SH-biowaste contaminations from slaughterhouses and wet markets and the effects on ecological system and human food chain

level of biochemical oxygen demand (BOD) tends to increase the concentrations of nitrates and ammonia in water bodies, which causes an increase in uncontrollable algae blooms.

In addition to organic wastes, the extensive use of arsenic in the poultry industry has raised ecological concerns (Hileman 2007; Lee et al. 2010). The application of arsenic is to increase the weight of poultry, prevent germs or parasites, and enhance the skin color of the poultry. But it has been reported that arsenic found in water bodies gives adverse effects on plants' growth, causes accumulation of microbe, and is closely related to cancer and skin diseases (Adesiyan et al. 2018).
Another biohazard from slaughterhouses and wet markets is the discharged antibiotics, resulting from the massive usage for diseases control and animal growth promoter (Maizatul et al. 2017). The most common antibiotics associated with slaughterhouse and wet market wastes are doxycycline, chlortetracycline, and sulfadiazine (Savin et al. 2020). Discharging antibiotic compounds directly into rivers or leachate directly impacts the living organisms in the water bodies and eventually harm aquatic life, leading to increased distribution of antibiotic-resistant bacteria in the environment (Maizatul et al. 2017). 
Table 3 Inedible portions of fish and shellfish as wastes (Michaela Archer 2001)

\begin{tabular}{llll}
\hline Type & Species & Inedible portion $(\%)$ & Inedible parts \\
\hline Fish & Catfish & $65 \%$ & Viscera, frame, skin, fin, and head \\
& Demersal (general) & $57 \%$ & \\
Haddock & $57 \%$ & \\
Hake & $50 \%$ & \\
Lemon sole & $58 \%$ & \\
Ling & $52 \%$ & Shell and viscera \\
Shellfish & $65 \%$ & \\
& Redfish & $70 \%$ & \\
& Whiting & $62 \%$ & \\
Crab & $68 \%$ & \\
Lobster & $56 \%$ & \\
Nephrops & $76 \%$ & \\
Shrimp & $65 \%$ & \\
Crustacea & $60 \%$ & \\
& Oyster & $61 \%$ & \\
Cockle & $86 \%$ & \\
Winkle & $77 \%$ & \\
Scallop & $86 \%$ & \\
Mussel & $86 \%$ & \\
Whelk & $58 \%$ & \\
Mollusc & & & \\
& & &
\end{tabular}

The wastewater from slaughterhouses and wet markets also contains several toxic materials, such as nitrate, detergents, surfactants, and chloric anions, which are classified as emerging contaminants (Latiffi et al. 2021). Both cationic and anionic surfactants are used in slaughterhouses for cleaning and disinfection purposes but are associated with increased total nitrogen and phosphorus concentrations in wastewater (Apandi 2020). All these factors cause the wastewater to become susceptible to the risk of infectious pathogens. Based on the bibliometric analysis for 500 published papers downloaded from the Scopus database using the keywords of "transmission" AND "slaughterhouse" OR "wet market" AND "pathogens" AND "water' OR "food", it was noted that the most common pathogenic bacteria associated with slaughterhouse and wet market wastewater include Salmonella spp., Listeria sp., E. coli, Shigella sp., and Staphylococcus sp. (Fig. 3).

Some common pathogenic bacteria in slaughterhouse and wet market wastes with infection potential have been identified and classified by the World Health Organization. These bacteria can be appropriately eliminated using sanitary methods, such as the filtration method and garbage pails. In some tropical countries, high cases of cholera, typhoid, malaria, dengue fever, and dysentery have been reported due to the increasing number of flies and mosquitoes found in the wastewater of slaughterhouses (Maizatul et al. 2017).

\section{Disease transmission and control}

Zoonotic transmission in slaughterhouses or wet markets is a threat to both the food industry and human health (Garcia et al. 2019; Guo et al. 2019). Campylobacter spp., Salmonella spp., Yersinia spp., Shiga toxin-producingEscherichia coli (STEC), Hepatitis E virus (HEV) from pigs, avian influenza virus, and other viruses are common pathogens detected in slaughterhouses (Maria 2014). With the recent outbreak of zoonotic diseases emerging from wet markets, such as SARSassociated coronavirus (SARS-CoV)(Mizumoto et al. 2020), this puts slaughterhouses and wet markets under the utmost attention. Hence, the public is concerned with the appropriate waste management and safe disposal regulations for disease prevention. Zoonotic transmission represents $60 \%$ of human pathogens from wildlife and livestock (Rahman et al. 2020). Workers in slaughterhouses are a high-risk group to become infected but have less knowledge of the threats of disease transmission (Fredriksson-Ahomaa 2014). A polluted environment at slaughterhouses due to the growth of microbes in the drainage is a big issue (Ketchell 2017). Investments in basic protective equipment, such as masks, gloves, and goggles to prevent direct contact with any discharges from animals, are lacking in many slaughterhouses (Department of Veterinary Services Malaysia 2018). Many abattoirs in rural areas have deplorable infrastructures, such as without proper rooftops and suitable water supply facilities, and animal flesh 


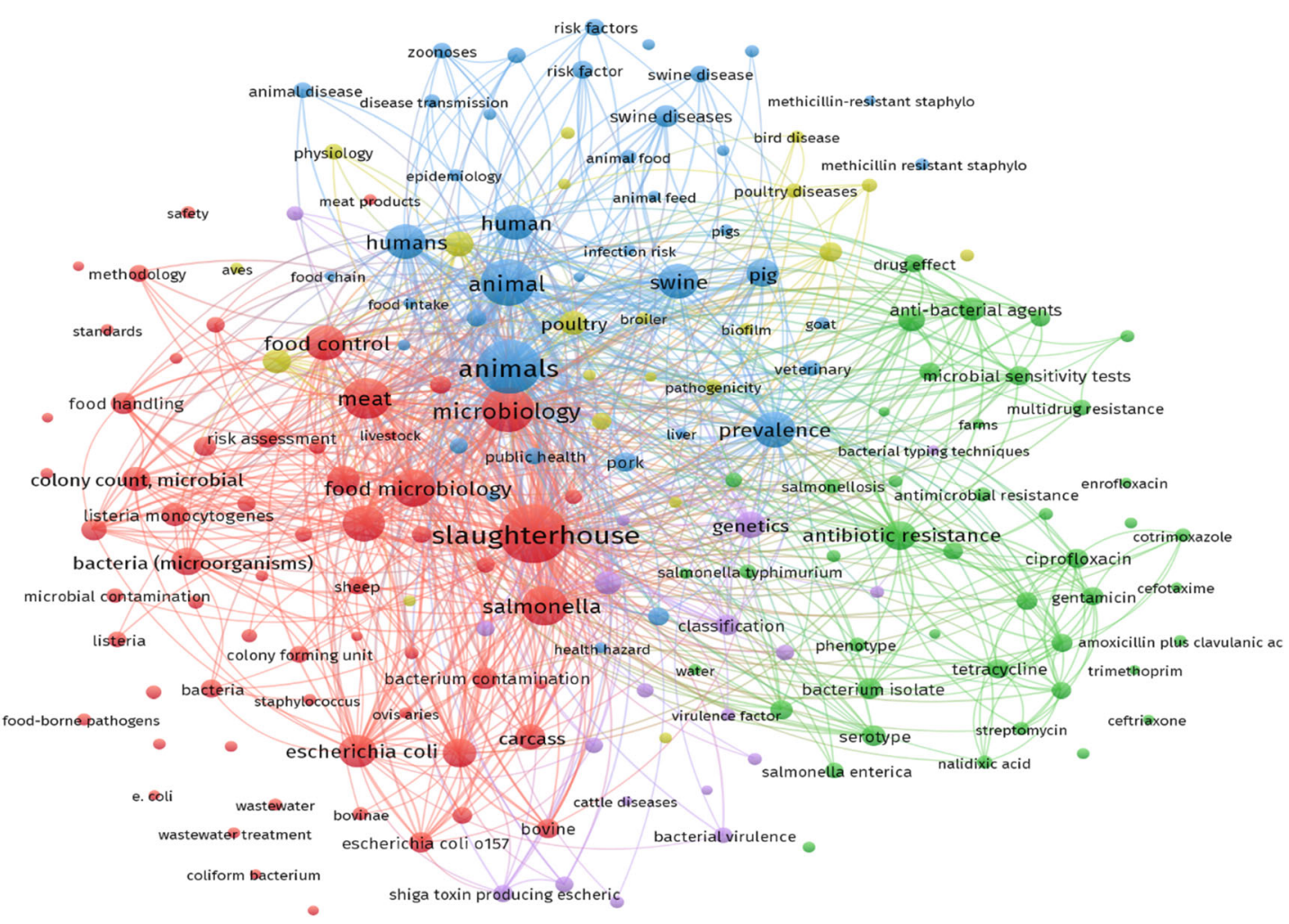

\& Vosviewer

Fig. 3 Interactions between SH-biowastes from slaughterhouses and wet markets, and most common bacterial strains in wastes as well as most common antibiotics used

being processed on the floor (Cook et al. 2017). Additionally, even sick animals are processed by some slaughterhouses to increase profit. Adonu et al. (2017) reported that several diseases could spread through sick animals and cause severe health issues for workers who are in direct contact with the animals in the slaughterhouses. This occurred because $70 \%$ of slaughterhouses are not properly controlled and inspected (Ketchell 2017).

Some slaughterhouses are combined with wet markets to reduce cost and offer fresh meat sources directly to the customers. These wet markets host vast types of wildlife, poultry, and even seafood, some of them together in stacked cages. Different types of animals are slaughtered at the same place, which escalates the chances of disease transmission (Steven 2020). SAR-CoV2 is an example of novel coronavirus transmission detected in the sewage pipeline of such joint wet markets (Medema et al. 2020). Therefore, in order to increase the knowledge to avoid another pandemic outbreak from meat reservoirs, refining the Meat Control Act (2012) integrated with the "One Health" policy demands immediate attention (Zheng et al. 2019). "One Health" is a program under the World Health Organization (WHO) to design and implement policies, programs, and legislation involving human and animal health in relation to public health, such as preventing a disease outbreak (Martin et al. 2017). The arrangement of mixed-animal slaughtering in the same slaughterhouse should be banned to avoid cross-contamination of microbes from different livestock to cut the potential of zoonotic transmission.

In addition, enhanced multi-sectional collaboration and data sharing between WHO partners and the Centers for Disease Control and Prevention (CDC) on public health are envisaged to ensure refinements in the prediction of viral emergence, disease severity, and reduction of disease transmission (Eisenstein 2018).

\section{Techniques for effective slaughterhouse SH-biowaste recycling}

The current biowaste segregation processes associated with the segregation of liquid and solid wastes are known as feedstock technologies. Segregation processes are key for reducing the health risk of slaughterhouse and wet market wastes and minimizing the survivability of infectious agents, where the solids in wastewater contribute effectively to the colonization of microbes. After segregation, the solid wastes from slaughterhouses and wet markets are collected and stored in a refuse room not exceeding $24 \mathrm{~h}$ to minimize the growth of fungi and bacteria (Noman et al. 2016). The solid wastes 
separated during different processes are skin trimmings, meat trimmings, dung, and rumens. Biowaste management technologies have evolved greatly from simple processes to the most efficient and high-end processes, which can be classified into four (4) categories, which are direct use of the biowastes generated, biological processes, physical-chemical processes, and thermo-chemical processes (Lohri et al. 2016). Currently, biological and thermo-chemical processes have gained tremendous attention from industries because these processes could recycle large amounts of biowastes in a short period of time. This paper will further discuss how biological and thermochemical processes are used as biowaste recycling technologies.

Biological processes are the conversion of biowastes by living organisms and require less energy consumption. Anaerobic digestion and composting are among the wellknown biowaste recycling methods for waste management. In well-developed and modernized slaughterhouses, highloading anaerobic reactors are used to treat effluents from slaughterhouses using high-rate anaerobic systems (Baker et al. 2020). There are two typical types of anaerobic reactors' feeding modes, which are batch reactor and continuous reactor. The simplest type of reactor is the batch reactor with agitation and heating, or a cooling process under a closed system. On the other hand, a continuous reactor is an open system that allows adding and removing materials or by-products. This type of reactor is well equipped with agitation to provide proper mixing of reactants.

These anaerobic reactors can be operated according to the reactors' temperature conditions, which are mesophilic and thermophilic anaerobic digestion conditions. Mesophilic anaerobic digestion involves bacteria/microbes primarily present at ambient temperatures ranging between 20 and $45^{\circ} \mathrm{C}$. On the other hand, thermophilic anaerobic digestion involves bacteria/microbes that can tolerate high temperatures in the range of 49 to $70^{\circ} \mathrm{C}$. The optimum performance of the system depends on the biological aspects of the anaerobic digestion ecosystem (Franke-Whittle and Insam 2013).

The anaerobic digestion technology is being used to utilize the biowastes and simultaneously produce methane as an alternative energy source (Yoon et al. 2014; Sari et al. 2016). The technology has several advantages, such as reducing carbon dioxide emissions, odors, and pathogenic disease transmission. This technology can save land spaces and are applicable to different types of wastes including solid or liquid wastes. Budiyono et al. (2011) reported that $48.89 \%$ of the biogas yielded is methane, $47.87 \%$ is $\mathrm{CO}_{2}$, and $2.43 \%$ is ammonia during the anaerobic digestion of lipid, carbohydrate, and fatty acid contents at certain temperatures.

The composting technique, on the other hand, is a common method to treat different wastes, such as manure, litter, and feathers from slaughtering activities, and recycle them into valuable bio-products(Salminen and Rintala 2002)(Fig. 4).
Table 4 presents information on the composting processes of wastes from slaughterhouses and wet markets along with their end product's (compost) characteristics. Large-scale poultry slaughterhouse wastes are mixed in different ratios with bulking agents, such as cardboards, agricultural waste, or sewage waste (Asses et al. 2019). Although there are concerns regarding the pathogens available in the compost and its possible infectious disease transmission, Asses et al. (2019) confirmed that the resultant compost is rich in effective microbial communities, while harmful pathogens such as Streptococci and Escherichia coli are not detected at the end of the process. Lou et al. (2015) also reported the reduction of pathogenic microorganisms in SH-biowaste compost, while the nutrients converted out of the compost can enhance soil fertility. The main products of composting processes are fully mineralized materials, such as $\mathrm{CO}_{2}, \mathrm{H}_{2} \mathrm{O}, \mathrm{NH}_{4}{ }^{+}$, stabilized organic matters heavily populated with competitive microbial biomasses, and ash. Based on the facility's requirements and energy consumption, the composting treatment can have a higher impact as compared with other treatments because composting may reduce the weight and volume of slaughterhouse and wet market biowastes dumped into landfills and reduce pathogenic microorganisms in the soil, and the nutrient conversion from the wastes can enhance soil properties.

Table 4 shows that separated biowastes, such as cow manure, have lower physical impurities compared with mixed biowastes (animal feedstock). Thus, mixed biowastes are subject to present higher environmental problems than separated biowastes depending on their characteristics. The physicochemical biowaste characteristics can be assessed through the American Public Health Association's (APHA) standard method for determining total nitrogen (TN), total phosphorus (TP), total organic carbon (TOC), total dissolved solids (TDS), and carbon-to-nitrogen ratio $(\mathrm{C} / \mathrm{N})$ (Table 1). Different characteristics of biowaste require different types of treatment necessary to deactivate pathogens and avoid disease outbreaks and environmental problems that are harmful to both humans and animals. The potential risks of infectivity associated with pathogen-contaminated biowaste tissues and prions have been comprehensively discussed in a previous study (Adhikari et al. 2018).

Thermo-chemical processes for biowaste recycling are widely used and include pyrolysis, liquefaction, incineration, and gasification. Thermal-chemical treatments are processes in which heat is applied to sanitize SH-biowastes, and the primary function of thermal treatments is to convert SHbiowastes into usable end products with a stable state and to reduce the final disposal of SH-biowastes in landfills (Staron et al. 2017). Thermal-chemical treatments are highly recommended by the Canadian Food Inspection Agency (CFIA) for the deactivation of available pathogens in SH-biowastes. Pyrolysis is conducted at high temperatures in low oxygen, while gasification is a thermal treatment technique that uses 


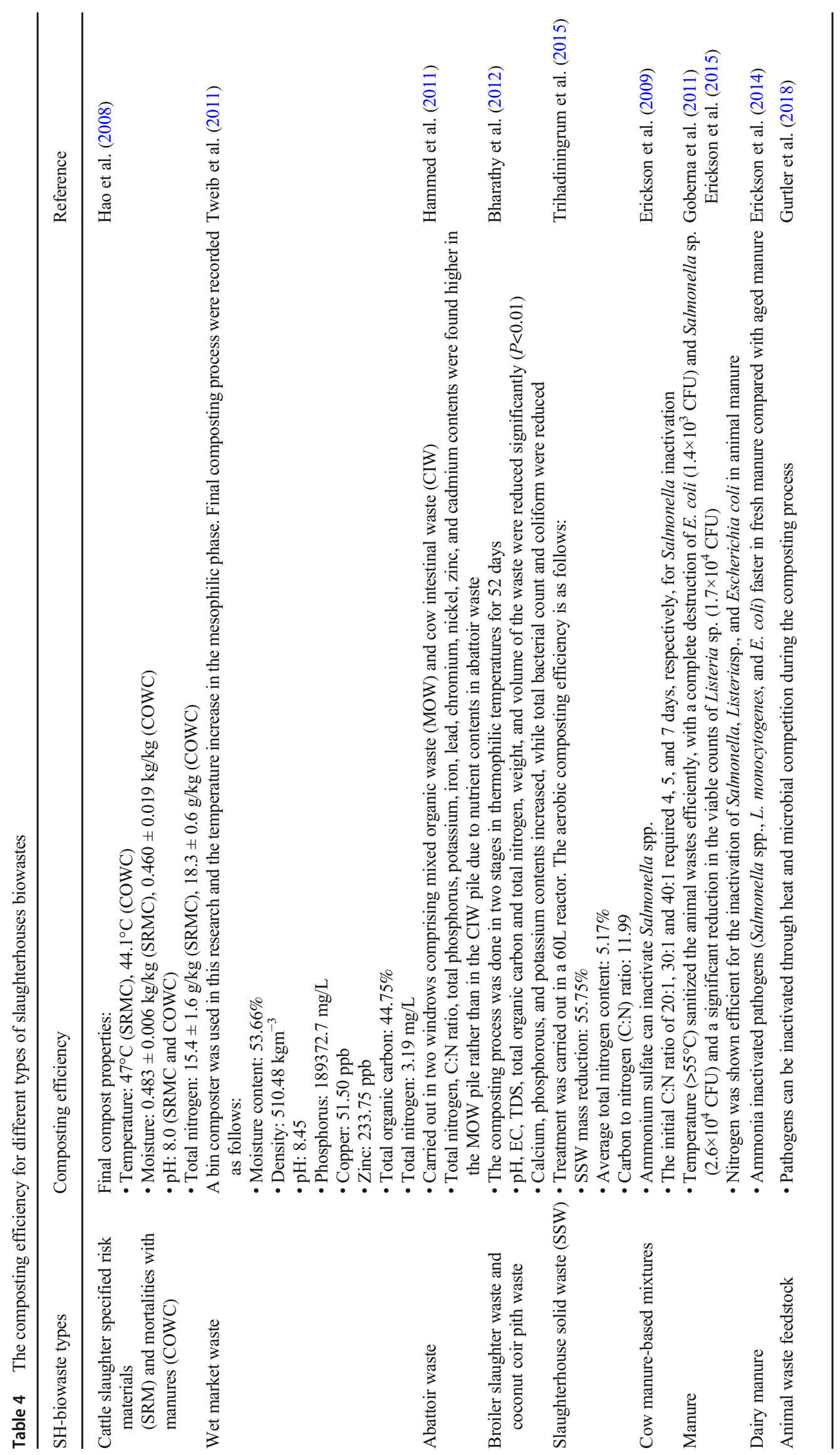


partial air. The emergence of pyrolysis, which works at high temperatures $\left(>500^{\circ} \mathrm{C}\right)$ in low or absence of oxygen, proposes a great potential in energy recovery. Incineration is the most effective method among all treatments, as it will kill all infectious agents that may present risks to human health and the environment (Tweib et al. 2011). Nevertheless, the downsides of the incineration method are the relatively slow process, higher cost, and stringent waste code criteria and capacity that the process is conducted in one facility (Sengupta 2004). The pyrolysis technique often produces greenhouse gases, such as carbon monoxide and nitrogen. Comparatively, incineration produces carbon dioxide $\left(\mathrm{CO}_{2}\right)$, oxygen $\left(\mathrm{O}_{2}\right)$, nitrogen $\left(\mathrm{N}_{2}\right)$, water, slag, and ash (Igalavithana et al. 2020).

Gasification is one of the thermal treatment techniques for partial oxidation at operating temperatures of 800 to $900^{\circ} \mathrm{C}$. Gasification produces composite gas or syngas primarily comprising carbon monoxide, hydrogen, methane, and carbon dioxide, including catalysts. The technology is widely used in slaughterhouse and wet market biowaste treatments, and it releases minimum gases into the atmosphere (Gusiatin et al. 2020). The gases generated from gasification are utilized as sources of energy for heating, transportation, and electrical power (Fig. 4).

The gasification process may release or absorb heat to the surroundings, depending on the system's design, the characteristics of the gas, and the calorific values and production of the by-products. The major benefit of the gasification of slaughterhouse and wet market biowastes is that the gas generated from gasification can be used directly to fuel a gas turbine system, thus improving the gasification thermal efficiency of the plant. Moreover, Gusiatin et al. (2020) reported that poultry ash, as the by-product of the gasification process, can remove toxic heavy metals, such as cadmium (Cd), from the wastewater. However, the main disadvantage of the gasification process is the higher initial capital investment for the construction and assembly of the thermal treatment equipment (Sari et al. 2016). This technique is associated with high upfront capital for the construction of complex equipment and infrastructure and with high plant maintenance and operation costs. In addition, this technique is restricted to small-scale waste loads, and thus large-scale applications require more complex treatment plants. Competent operators are needed to operate the plant continuously at an optimum condition, and additional energy is required (fuel and electricity).

Advanced biowaste recycling techniques are ideal for waste management, as these will reduce the threats to the public (spread of diseases, foul odors, and olfactory nuisance) and also the environment (air pollution and water and groundwater pollution). Additionally, biowaste recycling processes have evolved greatly due to the increasing demand for biowaste by-products and also due to limited landfills. The development of biowaste by-products can shift the economic paradigm toward a circular economy, which focuses on the recovery of resources and turning them back into valuable byproducts for commercialization. Thus, biowaste recycling technologies provide future opportunities for economic growth, as the technologies can act as a driving force for biowaste management business development. The recovery of nutrient sources, such as phosphorus and nitrogen, from biowaste recycling is a good opportunity for waste-to-wealth

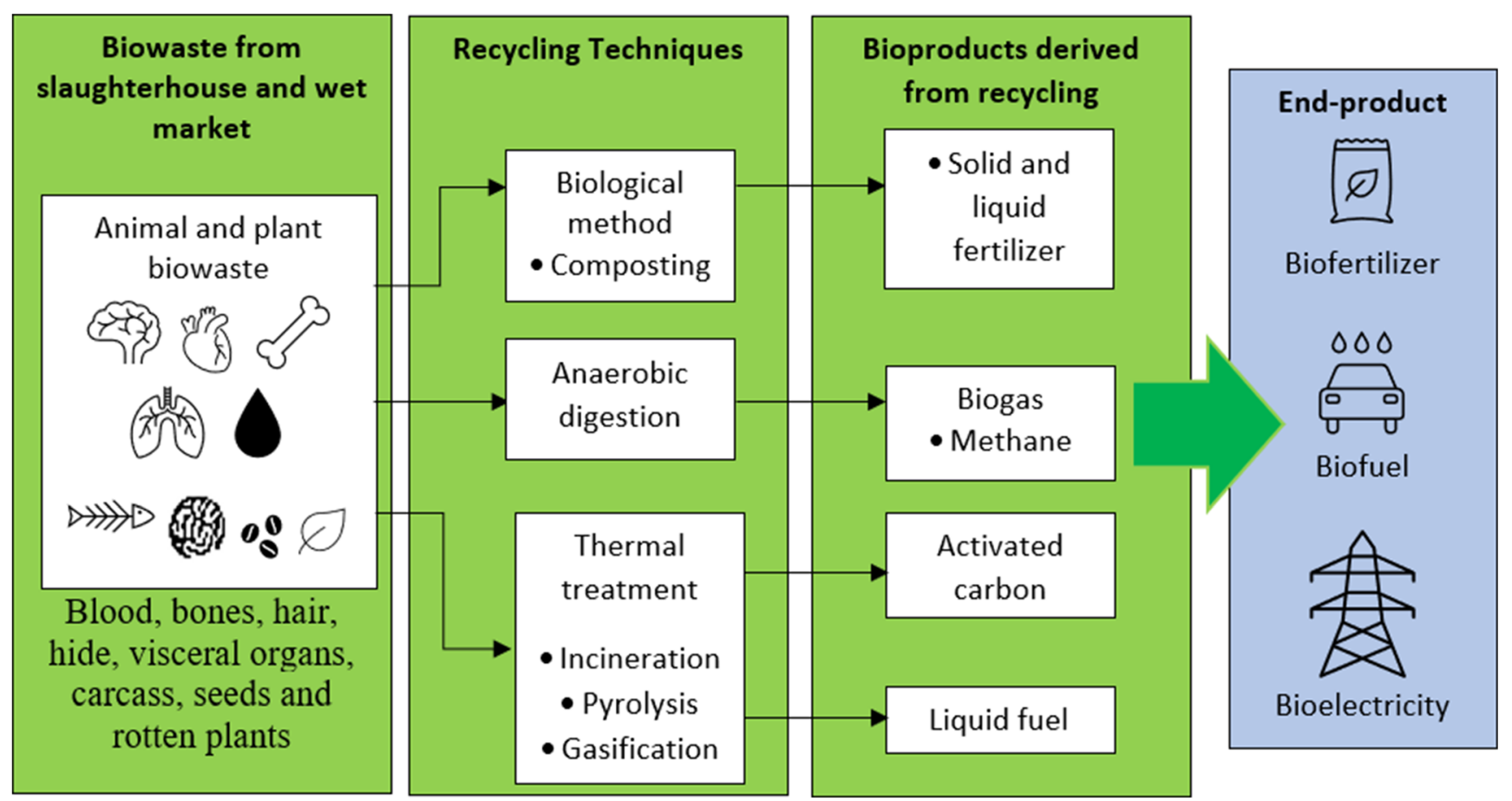

Fig. 4 Bio-products and renewable energy generated from SH-biowastes from slaughterhouses and wet markets using different recycling techniques 
product development and thus provides financial stability for biowaste businesses (Lohri et al. 2016). The market demand for biowaste recycling technologies will rise, as demand increases for waste products, such as stockfeed and fertilizers from animal biowastes, and also bio-energy as an alternative source of energy (Lohri et al. 2016).

\section{Conclusion}

With the rapid increase of the food production industry, health risk aspects associated with slaughterhouses and wet markets should not be neglected. Biowastes produced from slaughterhouses and wet markets are of a broad spectrum and these are the growing grounds for infectious disease. Different variances in slaughterhouse biowaste composition require proper sorting and segregation for efficient waste management and selection of efficient treatment methods. Developed countries have been applying automation in processing and recycling large-scale biowastes from slaughterhouses. This is in huge contrast with the processes in the slaughterhouses of underdeveloped countries, in which the slaughtering is performed in an under-privileged setup, with direct disposal of animal wastes into the land and water bodies. Therefore, the rotting of biowastes on land promotes environmental depletion, along with the growth of infectious diseases. Moreover, the accumulation of these biowastes in water bodies increases the content of nitrates and ammonia, inducing uncontrollable ecological problems, such as algae bloom. Land and river contaminations become more dreadful when pathogens and veterinary pharmaceutical chemicals are disposed through biowastes from slaughterhouses into water bodies.

Among various biowaste management techniques, biological and thermo-chemical processes have gained great consideration from industries due to the large recycling capacity and the short processing time. Moreover, the thermo-chemical technique produces gases that are sources for regenerating energy for heating, transportation, and electrical power. Additionally, the high organic contents of wastes from slaughterhouses and wet markets offer a lot of promising benefits for commercial purposes in the future, such as being used as fertilizers. Hence, biowaste recycling technologies provide future opportunities for biowaste management business development.

Author contribution AAG collected the data and drafted the manuscript. NLM analyzed the data and drafted the manuscript. PFR edited the manuscript. NS collected the biowaste data. MAY collected the data on advanced techniques for recycling and drafted the manuscript. RMSRM collected the data on current technology for waste management. CFS supervised, drafted, and edited the manuscript. All authors read and approved the final manuscript
Funding This research was funded by the Ministry of Higher Education Malaysia under the Research Excellence Consortium Grant Scheme (KKP) or KPM-Special Grant RMK-10 with reference number of JPT(BPKI)1000/016/018/25(54) or KKP Vot. No. K343.

Data availability Not applicable.

\section{Declarations}

Ethical approval Not applicable.

Consent for publication Not applicable.

Competing interests The authors declare no competing interests.

\section{References}

Adesiyan IM, Bisi-Johnson M, Aladesanmi OT, Okoh AI, Ogunfowokan AO (2018) Concentrations and human health risk of heavy metals in rivers in Southwest Nigeria. J Health Pollut 8:180907

Adeyemo OK (2002) Unhygienic operation of a city abattoir in South Western Nigeria: environmental implication. African J Environ Assess Ment Manag 4:23-28

Adhikari BB, Chae M, Bressler DC (2018) Utilization of slaughterhouse waste in value-added applications: Recent advances in the development of wood adhesives. Polymers 10:176

Adonu RE, Dzokoto L, Salifu SI (2017) Sanitary and hygiene conditions of slaughterhouses and its effect on the health of residents: a case study of Amasaman slaughterhouse in the Ga west municipality, Ghana. Food Sci Qual Manage 65:11-15

Alam MU, Rahman M, Islam MA, Asaduzzaman M, Sarker S, Rousham E, Unicomb L (2019) Human exposure to antimicrobial resistance from poultry production: assessing hygiene and waste-disposal practices in Bangladesh. Int J Hyg Environ Health 222:1068-1076

Aleksic N, Nesovic A, Sustersic V, Gordic D, Milovanovic D (2020) Slaughterhouse water consumption and wastewater characteristics in the meat processing industry in Serbia. Desalin Water Treat 190: 98-112

Alnahas F, Yeboah P, Fliedel L, Abdin AY, Alhareth K (2020) Expired Medication: societal, regulatory and ethical aspects of a wasted opportunity. Int J Environ Res Public Health 17:787

Anon (2002) The Animal By-Products Regulations (EC) no. 1774/2002. European Commission, Brussels

Apandi N (2020) Integrated growth potential of Scenedesmus sp. using public market wastewater via phycoremediation process. Int J Integr Eng 12:290-299

Arvanitoyannis IS, Kassaveti A (2008) Fish industry waste: treatments, environmental impacts, current and potential uses. Int J Food Sci Technol 43:726-745

Arvanitoyannis IS, Ladas D (2008) Meat waste treatment methods and potential uses. Int J Food Sci Technol 43:543-559

Asses N, Farhat W, Hamdi M, Bouallagui H (2019) Large scale composting of poultry slaughterhouse processing waste: microbial removal and agricultural biofertilizer application. Process Saf Environ Prot 124:128-136

Baker BR, Mohamed R, Al-Gheethi A, Aziz HA (2020) Advanced technologies for poultry slaughterhouse wastewater treatment: a systematic review. J Dispers Sci Technol 42:880-899

Bharathy N, Sakthivadivu R, Sivakumar K, Saravanakumar VR (2012) Disposal and utilization of broiler slaughter waste by composting. Vet World 5:359-361 
Budiyono IN, Widiasa S, Johari S (2011) Study on slaughterhouse wastes potency and characteristic for biogas production. Int J Waste Resour $1: 4-7$

Bustillo-Lecompte C, Mehrvar M (2017) Slaughterhouse wastewater: treatment, management and resource recovery. Physico-chemical wastewater treatment and resource recovery:153-174

Chang X, Meyer MT, Liu X, Zhao Q, Chen H, Chen J, Qiu Z, Yang L, Cao J, Shu W (2010) Determination of antibiotics in sewage from hospitals, nursery and slaughter house, wastewater treatment plant and source water in Chongqing region of Three Gorge Reservoir in China. Environ Pollut 158:1444-1450

Ching-Velasquez J, Fernández-Lafuente R, Rodrigues RC, Plata V, Rosales-Quintero A, Torrestiana-Sánchez B, Tacias-Pascacio VG (2020) Production and characterization of biodiesel from oil of fish waste by enzymatic catalysis. Renew Energy 153:1346-1354

Cook EAJ, de Glanville WA, Thomas LF, Kariuki S, de Clare Bronsvoort BM, Fèvre EM (2017) Working conditions and public health risks in slaughterhouses in western Kenya. BMC Public Health 17:14

Damaceno FM, Buligon EL, Restrepo JCPS, Chiarelotto M, Niedzialkoski RK, de Mendonça Costa LA, de Lucas JJ, de Mendonça Costa MSS (2019)Semi-continuous anaerobic codigestion of flotation sludge from broiler chicken slaughter and sweet potato: nutrients and energy recovery. Sci Total Environ 683:773-781

Department of Veterinary Services Malaysia (2018) Peninsular Malaysia: recorded slaughter of livestock. Department of Veterinary Services Malaysia (DVS). Retrieve on 30 March 2020 from: http://www.dvs. gov.my/dvs/resources/user_1/2019/BP/Perangkaan\%20Ternakan\% 2020182019/)_Sem.Malaysia_Sembelihan_Ternakan_pdf

Diarra S, Sandakabatu D, Perera D, Tabuaciri P, Mohammed U (2015) Growth performance and carcass yield of broiler chickens fed commercial finisher and cassava copra meal-based diets. Appl Anim Res 43:352-356

Eisenstein M (2018) Infection forecasts powered by big data. Nature 555(7695):S2-S4

Erickson MC, Liao J, Maa L, Jiang X, Doyle MP (2009) Inactivation of Salmonella spp. in cow manure composts formulated to different initial C: N ratios. Bioresour Technol 100:5898-5903

Erickson MC, Liao J, Jiang X, Doyle MP (2014) Inactivation of pathogens during aerobic composting of fresh and aged dairy manure and different carbon amendments. J Food Prot 77:1911-1918

Erickson MC, Smith C, Jiang X, Flitcroft ID, Doyle MP (2015) Manure source and age affect survival of zoonotic pathogens during aerobic composting at sublethal temperatures. J Food Prot 78:302-310

FAO (2021) Food and Agriculture Organization United Nation, http:// www.fao.org/faostat/en/, 2018. Accessed 29 Jun 2021

Fearon J, Mensah SB, Boateng V (2014) Abattoir operations, waste generation and management in the Tamale metropolis: case study of the Tamale. J Public Health Epidemiol 6:14-19

Franke-Whittle IH, Insam H (2013) Treatment alternatives of slaughterhouse wastes, and their effect on the inactivation of different pathogens: a review. Crit Rev Microbiol 39:139-151

Fredriksson-Ahomaa M (2014) Public Health Hazards: A. Biological Hazards. Meat Inspection and Control in the Slaughterhouse, 277333

Garcia SN, Osburn BI, Cullor JS (2019) A one health perspective on dairy production and dairy food safety. One Health 7:100086

Gendebien A, Ferguson R, Brink J, Horth H, Sullivan M, Davis R, Brunet H, Dalimier F, Landrea B, Krack D, Perot J, Orsi C (2001) Survey of wastes spread on land - Final Report, Study Contract B4-3040/99/ 110194/MAR/E3, European Commission

Goberna M, Podmirseg SM, Waldhuber S, Knapp BA, García C, Insama $\mathrm{H}$ (2011) Pathogenic bacteria and mineral $\mathrm{N}$ in soils following the land spreading of biogas digestates and fresh manure. Appl Soil Ecol 49:18-25
Goldstrand RE (1992) An overview of inedible meat, poultry and fishery by-products. In Inedible Meat By-Products, pp 1-17. Springer, Dordrecht

Guo Z, Li B, Shunlong G (2019) Government regulations and voluntary certifications in food safety in China: a review. Trends Food Sci Technol 90:160-165

Gurtler JB, Doyle MP, Erickson MC, Jiang X, Millner P, Sharma M (2018) Composting to inactivate foodborne pathogens for crop soil application: a review. J Food Prot 81:1821-1837

Gusiatin ZM, Kulikowska D, Klik B (2020)New-generation washing agents in remediation of metal-polluted soils and methods for washing effluent treatment: a review. Int J Environ Res Public Health 17: 6220

Hammed TB, Soyingbe AA, Adewole DO (2011) An Abattoir wastewater management through composting: a case study of Alesinloye waste recycling complex. Int J Interdiscip Soc Sci 6:1-19

Hao X, Stanford K, McAllister TA, Larney FJ, Xu S (2008) Greenhouse gas emissions and final compost properties from co-composting bovine specified risk material and mortalities with manure. Nutr Cycl Agroecosyst 83:289-299

Hileman B (2007) Arsenic in chicken production: a common feed additive adds arsenic to human food and endangers water supplies. Government and Policy 85:34-35

Ho K, Chu LM (2019) Characterization of food waste from different sources in Hong Kong. J Air Waste Manag Assoc 69:277-288

Igalavithana AD, Choi SW, Dissanayake PD, Shang J, Wang CH, Yang X, Kim S, Tsang DC, Lee KB, Ok YS (2020) Gasification biochar from biowaste (food waste and wood waste) for effective $\mathrm{CO}_{2}$ adsorption. J Hazard Mater 391:121147

Ketchell M (2017) From farm to table: poor hygiene in slaughterhouses in rural Kenya. https://theconversation.com/from-farm-to-table-poorhygiene-in-slaughterhouses-in-rural-kenya-71820

Latiffi N, Mohamed R, Al-Gheethi A, Tajuddin R (2021) Harvesting of Scenedesmus sp. after phycoremediation of meat processing wastewater; optimization of flocculation and chemical analysis of biomass. J Chem Technol Biotechnol 96:254-261

Lee CS, Chang CH, Wen CG, Chang SP (2010) Comprehensive nonpoint source pollution models for a free-range chicken farm in a rural watershed in Taiwan. Agric Ecosyst Environ 139:23-32

Lohri CR, Rajabu HM, Sweeney DJ, Zurbrugg C (2016) Char fuel production in developing countries-a review of urban biowaste carbonization. Renew Sustain Energy Rev 59:1514-1530

Lou Z, Wang M, Zhao Y, Huang R (2015) The contribution of biowaste disposal to odor emission from landfills. J Air Waste Manag Assoc $65: 479-484$

Maizatul A, Mohamed R, Al-Gheethi A, Hashim M (2017) An overview of the utilisation of microalgae biomass derived from nutrient recycling of wet market wastewater and slaughterhouse wastewater. Int Aquat Res 9:177-193

Maria FA (2014) Public Health Hazards: A. Biological Hazards. Meat Inspection and Control in the Slaughterhouse, Thimjos Ninios (ed), pp 277-333

Martin H, Roberto E, Massimo C, Maurizio A, Rüegg B (2017) Knowledge integration in one health policy formulation, implementation and evaluation, (ed) W.H.O. (WHO)

Matsumura EM, Mierzwa JC (2008) Water conservation and reuse in poultry processing plant - a case study. Resour Conserv Recycl $52: 835-842$

Medema G, Heijnen L, Elsinga G, Italiaander R, Brouwer A (2020) Presence of SARS-Coronavirus-2 in sewage. MedRxiv

Mensah-Attipoe J, Toyinbo O (2019) Fungal growth and aerosolization from various conditions and materials. Fungal Infec: $1-10$

Michaela Archer (2001) Fish waste production in the United Kingdom. Seafish report number SR537, The Sea Fish Industry Authority, United Kingdom, November 2001 
Mizumoto K, Kagaya K, Chowell G (2020) Effect of the wet market on the coronavirus disease (COVID-19) transmission dynamics in China, 2019-2020. Int J Infect Dis 97:96-101

NABC (2004) Carcass disposal: a comprehensive review. Report written for the USDA Animal and Plant Health Inspection Service. National Agricultural Biosecurity Centre, Kansas State University, USA., 2004

Noman EA, Rahman N, Shahadat M, Nagao H, Al-Karkhi A, Al-Gheethi A, Lah T, Omar AK (2016) Supercritical fluid $\mathrm{CO}_{2}$ technique for destruction of pathogenic fungal spores in solid clinical wastes. Clean-Soil Air Water 44:1700-1708

Oh WY, Lee WS, Lee SS, Khan MA, Ko MS, Yang SH, Kim H, Ha JK (2008) Feed consumption, body weight gain and carcass characteristics of Jeju Native Cattle and its crossbreds fed for short fattening period. Asian-Australas J Anim Sci 21:1745-1752

Rahman M, Sobur M, Islam M, Ievy S, Hossain M, El Zowalaty ME, Rahman A, Ashour HM (2020) Zoonotic diseases: etiology, impact, and control. Microorganisms 8:1405

Ratnawati R, Trihadiningrum Y (2014) Slaughter house solid waste management in Indonesia. J Biol Res 19:69-73

Ravanipour M, Bagherzadeh R, Mahvi AH (2021) Fish and shrimp waste management at household and market in Bushehr. Iran J Mater Cycles Waste Manag 23:1394-1403. https://doi.org/10.1007/ s10163-021-01219-2

Russ W, Meyer-Pittroff R (2004) Utilizing waste products from the food production and processing industries. Crit Rev Food Sci Nutr 44: $57-62$

Salminen E, Rintala J (2002) Anaerobic digestion of organic solid poultry slaughterhouse waste-a review. Bioresour Technol 83:13-26

Sari OF, Ozdemir S, Celebi A (2016) May. Utilization and management of poultry slaughterhouses waste with new methods. In Eurasia 2016 Waste Management Symposium

Savin M, Bierbaum G, Hammerl JA, Heinemann C, Parcina M, Sib E, Voigt A, Kreyenschmidt J (2020)Antibiotic-resistant bacteria and antimicrobial residues in wastewater and process water from German pig slaughterhouses and their receiving municipal wastewater treatment plants. Sci Total Environ 727:138788
Sengupta B (2004) Solid waste management in slaughter house, published by Central Pollution Control Board (CPCB). Ministry of Environment and Forests, Delhi

Shija DS, Mtenga L, Kimambo A, Laswai G, Mushi D, Mgheni D, Mwilawa A, Shirima E, Safari J (2013) Preliminary evaluation of slaughter value and carcass composition of indigenous sheep and goats from traditional production system in Tanzania. AsianAustralas J Anim Sci 26:143-150

Staron P, Kowalski Z, Staron A, Banach M (2017) Thermal treatment of waste from the meat industry in high scale rotary kiln. Int J Environ Sci Technol 14:1157-1168

Steven LM (2020) China's omnivorous markets are in the eye of a lethal outbreak once again. The New York Times. https://www.nytimes. com/2020/01/25/world/asia/china-markets-coronavirus-sars.html

Trihadiningrum Y, Ratnawati R, Wulandari R, Radita DR, Juliastuti S (2015) Comparison of slaughterhouse solid waste treatment using anaerobic-anoxic-oxic and aerobic composting methods. In $5^{\text {th }}$ Environmental Technology and Management Conference (ETMC). Bandung, Indonesia

Tweib SA, Rahman RA, Khalil MS (2011) composting of solid waste from wet market of Bandar Baru Bangi Malaysia. Aust J Basic Appl Sci 5:975-983

Woodard, Curran, Inc (2006) Chapter 10 - Wastes from Industries (Case Studies), Editor(s): Woodard and Curran. Inc, Industrial Waste Treatment Handbook (Second Edition), Butterworth-Heinemann, pp 409-496. https://doi.org/10.1016/B978-075067963-3/50012-6

Yoon YM, Kim SH, Oh SY, Kim CH (2014) Potential of anaerobic digestion for material recovery and energy production in waste biomass from a poultry slaughterhouse. J Waste Manag 34:204-209

Zheng Z, Lu Y, Short KR, Lu J (2019) One health insights to prevent the next HxNy viral outbreak: learning from the epidemiology of H7N9. BMC Infect Dis 19:138

Publisher's note Springer Nature remains neutral with regard to jurisdictional claims in published maps and institutional affiliations. 